\title{
Benthic community metabolism in a coastal lagoon ecosystem
}

\author{
Barbara L. Nowicki \& Scott W. Nixon \\ Graduate School of Oceanography, University of Rhode Island, Narragansett, Rhode Island 02882-1197, USA
}

\begin{abstract}
Measurements of benthic oxygen production and consumption at 3 stations over an annual cycle in a shallow (mean depth $=0.7 \mathrm{~m}$ ) coastal lagoon on the Rhode Island (USA) coast provide evidence that shallow benthic communities may consume more organic matter than can be provided by impressive rates of in situ epifloral production. While sandy sediment areas in Potter Pond lagoon showed a net daytime production of about $140 \mathrm{~g} \mathrm{C} \mathrm{m}^{-2} \mathrm{yr}^{-1}$, the more extensive areas of fine-grained sediment did not show any significant amount of net benthic daytime production annually. Moreover when nighttime respiratory costs were included, the lagoon benthos as a whole showed a net organic consumption of $30 \mathrm{~g} \mathrm{C} \mathrm{m}^{-2} \mathrm{yr}^{-1}$ in spite of a net annual daytime production rate of $50 \mathrm{~g} \mathrm{C} \mathrm{m}^{-2} \mathrm{yr}^{-1}$. Rates of in situ oxygen uptake by fine-grained lagoon sediments in the dark were not separable from those of similar sediments in much deeper (mean $=8.6 \mathrm{~m}$ ) Narragansett Bay. For the lagoon as a whole, the benthos consumed about 40 to $50 \%$ of the combined primary production by phytoplankton, macrophytes and benthic epiflora. This partitioning is similar to that found in deeper, plankton-based systems with completely heterotrophic bottom communities.
\end{abstract}

\section{INTRODUCTION}

The fact that much of the organic matter produced in many estuarine and coastal waters is consumed by the benthos has been well documented (Zeitzschel 1980, Nixon 1981). However, almost all of our information concerning the coupling between benthic and pelagic communities has come from relatively deep systems in which heterotrophic bottom communities are supported by phytoplankton production. Less studied have been the shallow coastal lagoon systems which characterize 10 to $15 \%$ of the world coastline (Cromwell 1971). In these shallow areas sunlight often penetrates to the bottom and organic matter reaching the benthos may be from seagrasses, macroalgae, and benthic microflora in addition to phytoplankton within the water column.

The measurement of benthic community metabolism in these systems is difficult because light must be included as a variable. It is also necessary to account for benthic organic production as well as decomposition, and for benthic nutrient uptake as well as remineralization. While numerous studies have reported the production of seagrasses and, much less frequently, that of macroalgae and microflora in a variety of lagoons, very little attention has been given to heterotrophic benthic metabolism in these environments. It is rarer still to find data available from both autotrophic and heterotrophic components of the benthos in order to describe the net metabolic balance of the bottom as a whole and its contribution to the total metabolism of the lagoon.

This study presents the results of in-situ benthic community respiration and production measurements made in Potter Pond, a shallow coastal lagoon on the ocean coast of Rhode Island, USA. Because $60 \%$ of the area of this lagoon is less than one meter deep, the ratio of sediment surface to water volume is relatively large, and the benthos was expected to play a substantial role in the flow of energy and nutrients. This paper describes the benthic production and consumption of organic matter, but nutrient exchanges were also measured and are reported separately (Nowicki \& Nixon in press).

\section{STUDY SITE}

Although referred to locally as a 'salt pond', Potter Pond (Fig. 1) is actually a coastal lagoon separated from the open ocean by a barrier spit and connected to the sea through a permanent breachway. It has a mean annual salinity of 27 to $28 \%$, receives freshwater on its 


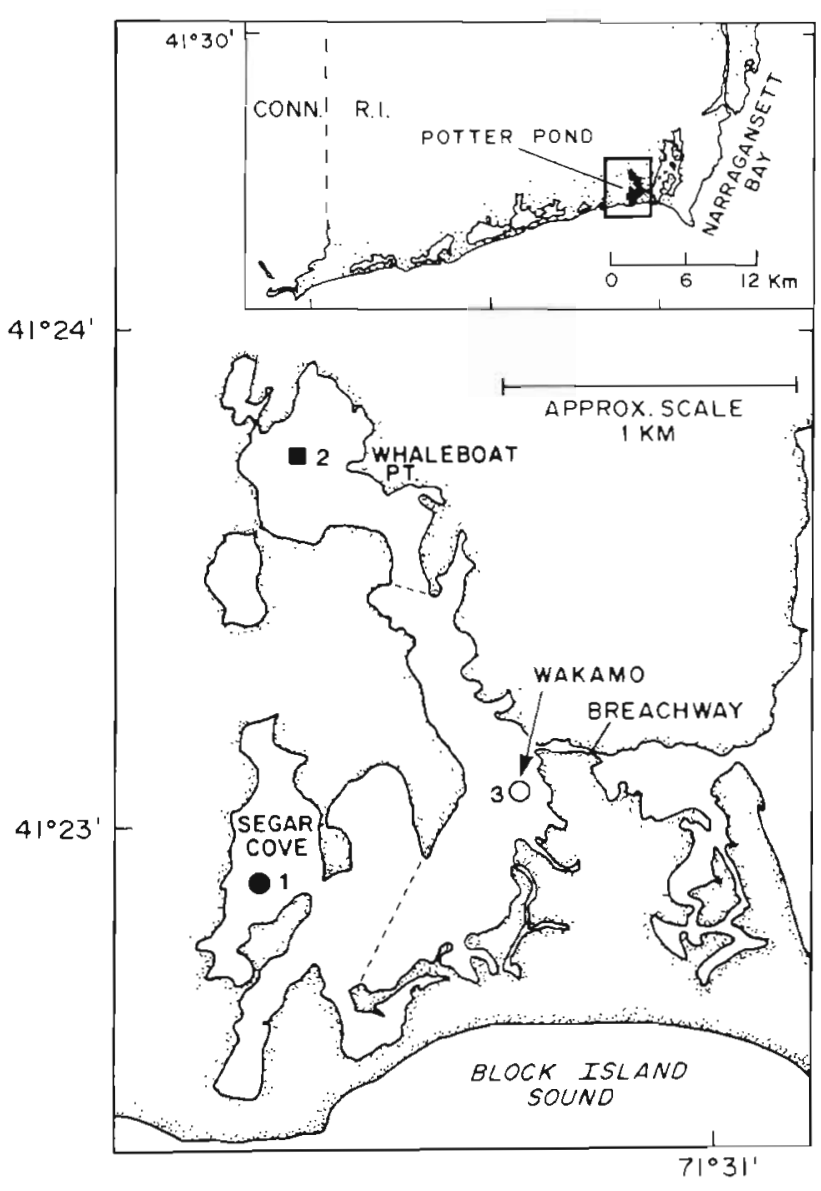

POTTER POND, RHODE ISLAND

Fig. 1. Locations of the 3 stations where benthic metabolism measurements were made in Potter Pond lagoon. Annual estimates of benthic respiration and production at each station were area-weighted by sediment type to derive estimates for the pond benthos as a whole. Mud sediments at Stations 1 and 2 represented 43 and $22 \%$ of the total pond area; sandy sediments on the tidal flat surrounding Station 3 (dashed lines) comprised $35 \%$ of the pond bottom

landward margin from groundwater and a small amount of surface runoff, and exchanges salt water twice each day with Block Island Sound. The tidal range in the lagoon is about $20 \mathrm{~cm}$. Potter Pond has a total area of $1.35 \times 10^{6} \mathrm{~m}^{2}$, a mean depth of $0.68 \mathrm{~m}$, and $60 \%$ of the lagoon is less than $1 \mathrm{~m}$ deep at mean low water. Vertical light extinction coefficients range from 0.4 to $2.10 \mathrm{~m}^{-1}$ with an average $\mathrm{K}$ of $1.2 \mathrm{~m}^{-1}$ ( 3 stations over 1 annual cycle), so that for a mean depth of $0.68 \mathrm{~m}$ approximately $45 \%$ of incident radiation reaches the pond bottom. Shallow depth and light penetration have encouraged abundant macrophyte growth over much of the area. Thorne-Miller and Harlin (pers. comm.) have estimated an annual production by Zostera marina of 200 to $400 \mathrm{~g}$ dry $w t \mathrm{~m}^{-2}$ and a production of approximately $250 \mathrm{~g}$ dry wt $\mathrm{m}^{-2}$ of mac- roalgae. Measurements of chlorophyll $a$ in surface sediments (mean 170, range 10 to $460 \mathrm{mg} \mathrm{m}^{-2}$ during Feb-Oct) suggest an active benthic microflora as well. The pond exhibits a wide annual temperature range from $-1.5^{\circ} \mathrm{C}$ (ice cover) in winter to a high of $28^{\circ} \mathrm{C}$ in mid summer.

Measurements of benthic metabolism were made over a 2 yr period (Oct 1979-Oct 1981) at 3 stations in the lagoon (Fig. 1). Stations 1 and 2 were located in coves, where restricted circulation resulted in accumulation of mud sediments. Combustion of surface sediments $\left(450^{\circ} \mathrm{C}\right.$ for $\left.4 \mathrm{~h}\right)$ from these 2 stations indicated approximately $15 \%$ organic matter. Station 3 was located on a sandy sub-tidal flat near the lagoon breachway and was swept clear of organic debris by tides and wind. Surface sediments on the sandy tidal flat showed only $2 \%$ weight loss on ignition.

\section{MATERLALS AND METHODS}

Field measurements. Measurements of the net flux of oxygen between sediments and overlying water were made using transparent and opaque chambers at one or another of the 3 sites on 30 occasions between October 1979 and October 1981. On each occasion duplicate light and dark Plexiglas chambers were placed over the bottom sediments. Details of the benthic chamber construction are given in Fig. 2. Chambers were carefully deployed using mask and snorkel or SCUBA gear so that bottom sediments remained undisturbed. In some instances sediment flux measurements were made within beds of Zostera marina and in the presence of macroalgae, though chambers were always positioned so as to exclude the macrophyte plants themselves. Estimates of macrophyte production have been made in a separate study by Thorne-Miller and Harlin (pers. comm.) and will be cited in sections to follow. Incubation times ranged from 4 to $8 \mathrm{~h}$, depending on water temperature, and were carefully controlled to prevent oxygen levels within the chambers from dropping below $4 \mathrm{mg} \mathrm{O}_{2} \mathrm{l}^{-1}$.

In addition to chamber incubations, a series of light and dark glass $300 \mathrm{ml}$ BOD bottles were filled with pond water and used as control bottles for assessing changes in nutrient and oxygen concentrations in the water column. Dissolved oxygen was measured using the modified Winkler technique (Carritt \& Carpenter 1966). Samples were taken with large plastic syringes fitted with $4 \mathrm{~mm}$ diameter tygon tubing, and placed in $60 \mathrm{ml}$ BOD bottles. Winkler reagents were added immediately, and the fixed samples kept dark until titration. Samples for nutrient analysis were taken concurrently with oxygen samples and have been described separately (Nowicki \& Nixon in press).

The 'benthic flux' method assumes a linear change 
in oxygen concentrations over time with samples taken at the beginning and end of the incubation period. Linearity was checked in the field by following the change in dissolved oxygen over time in sealed benthic chambers with an oxygen probe (Beckman field oxygen meter) inserted in the sample port. We have also found a linear uptake of oxygen by the benthos in numerous laboratory experiments provided that the oxygen concentration in the overlying water does not drop below $4 \mathrm{mg} \mathrm{O} \mathrm{O}^{-1}$.

At regular intervals during the incubation, light meter measurements were made through the water column (Li-Cor 192S Quantum Meter) and an extinction coefficient calculated. Because the pond is tidal, the depth of water over the chambers was measured

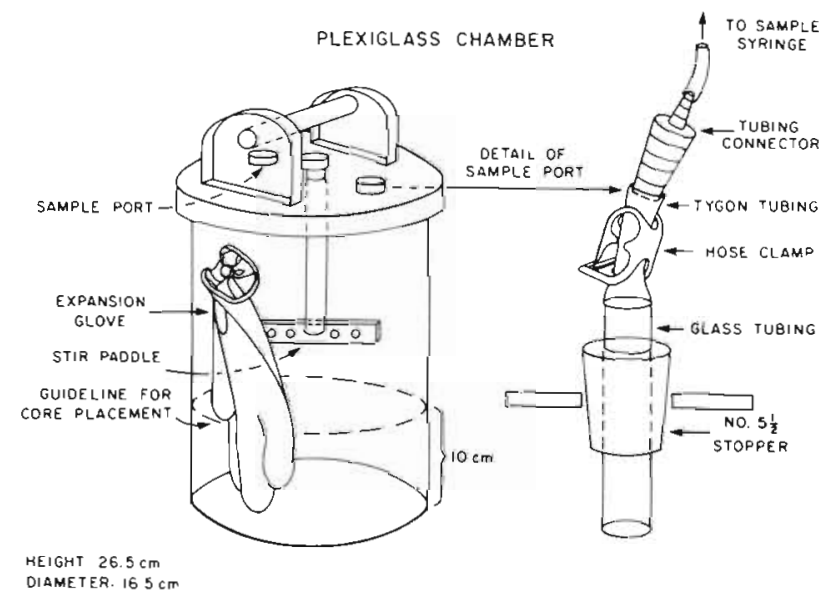

Fig. 2. Benthic chamber used for in-situ measurements of oxygen exchange at the sediment-water interface in Potter Pond lagoon. Each chamber was pushed into the sediments to a depth of $10 \mathrm{~cm}$, covered an area of $0.02 \mathrm{~m}^{2}$, and contained approximately $3 \mathrm{l}$ of overlying water. A rubber surgical glove attached to a port on the chamber side functioned as an expansion chamber and allowed water to be withdrawn from the sealed benthic chamber without admitting surrounding pond water or sediment pore waters. A sample tube on the top of the chamber was clamped and unclamped to withdraw samples as needed, and a stirring paddle could be turned manually from outside the chamber before each sample was taken

over time as well. Water temperature was recorded at the time of initial and final samples on the day of sampling as well as weekly over an annual cycle at each station. Water-column chlorophyll a was measured at each station weekly from October 1980 through October 1981 using the method given by Holm-Hansen et al. (1965). Sediment chlorophyll a (surface $1 \mathrm{~cm}$ ) was measured weekly from February through October, and analyzed by extraction in $90 \%$ acetone at $5{ }^{\circ} \mathrm{C}$ using alternating periods of ultrasonification and centrifugation. Both sediment and water column chlorophyll a were measured with a Turner Model 110 fluorometer.
Benthic respiration. In order to extrapolate from our short-term dark chamber measurements to estimates of annual benthic respiration for the lagoon as a whole, dark chamber oxygen uptake measurements $\left(\mathrm{mg} \mathrm{O}_{2}\right.$ $\mathrm{m}^{-2} \mathrm{~h}^{-1}$ ) were corrected for dark uptake by the water column and regressed against temperature for each of the 3 stations. These temperature regressions were then used with weekly temperature data to predict hourly rates of oxygen uptake in the dark throughout the year. Data from Eppley Laboratories (Newport, RI) were used to determine the number of daytime and nighttime hours and combined with hourly rates to give annual curves of benthic daytime and nighttime respiration. Integration of the area under these curves gave an estimate of total annual benthic oxygen uptake. Oxygen was converted to carbon assuming an $\mathrm{RQ}$ of 1 (Nixon et al. 1980) to yield annual respiratory demands for the benthos in terms of $\mathrm{g} \mathrm{C} \mathrm{m}^{-2} \mathrm{yr}^{-1}$. This process was repeated for each station independently and the results area-weighted by sediment type (Fig. 1) to give an integrated total for Potter Pond as a whole.

Specific values for $R Q$ and $P Q$ were not available for the water column or benthos of Potter Pond, so these numbers were assumed from work in nearby Narragansett Bay. An RQ of 1 was chosen from empirically determined values for sediment cores from the Bay (Nixon et al. 1980), and a $P Q$ value was taken from work by Oviatt et al. (1981) for Narragansett Bay phytoplankton.

Benthic production. Estimates of net daytime production for the lagoon microbenthos were derived from oxygen fluxes in transparent light chambers. Hourly rates of light chamber benthic oxygen flux $\left(\mathrm{mg} \mathrm{O}_{2} \mathrm{~m}^{-2}\right.$ $\mathrm{h}^{-1}$ ) were corrected for changes occurring in corresponding water column bottles, and regressed against temperature and light received for each station in the Pond. These regressions were used with weekly temperature data and light data to predict an annual cycle of net benthic oxygen flux during daylight hours. Integrated annual oxygen flux values were converted to carbon assuming a PQ of 1 to yield estimates of annual net daytime benthic production for each station. Independent estimates for each station were then areaweighted by sediment type to give an integrated total for the Potter Pond benthos as a whole. Net production of seagrasses and macroalgae was determined in a separate study by Harlin and Thorne-Miller (pers. comm.).

\section{RESULTS}

\section{Benthic respiration}

Benthic oxygen uptake rates in dark chambers ranged from 15 to $190 \mathrm{mg} \mathrm{O}_{2} \mathrm{~m}^{-2} \mathrm{~h}^{-1}$ with highest 
rates observed on mud sediments. Dark-chamber oxygen uptake rates were significantly lower in sandy sediments ( $\mathrm{p}=0.003)$ and did not show the dramatic increase with temperature observed at mud sediment stations (Fig. 3). On the sandy tidal flat at Wakamo, temperature had little effect, and benthic uptake rates averaged $40 \mathrm{mg} \mathrm{O} \mathrm{m}^{-2} \mathrm{~h}^{-1}$ over a temperature range from 4.0 to $22.5^{\circ} \mathrm{C}$ (Fig. 3).

Oxygen uptake over an annual cycle was estimated using an exponential model of respiration as a function of water temperature at the 2 mud bottom stations (Fig. 3) combined with weekly water temperature data. The result suggests that the mud sediments at Segar Cove and Whaleboat Point consumed between 70 and $100 \mathrm{~g}$ $\mathrm{C} \mathrm{m}{ }^{-2} \mathrm{yI}^{-1}$ in nighttime respiration and 95 to $125 \mathrm{~g} \mathrm{C}$ $\mathrm{m}^{-2} \mathrm{yr}^{-1}$ in daytime respiration (Fig. 4).

Since benthic respiratory rates on the sandy subtidal flat area were unaffected by temperature, a simple mean uptake rate was applied throughout an annual cycle. Thus, an annual plot of benthic oxygen uptake shows variation only with the length of day and night throughout the year (Fig. 4). The sandy area was estimated to consume $70 \mathrm{~g} \mathrm{C} \mathrm{m}^{-2} \mathrm{yr}^{-1}$ in benthic respiration during both daytime and nighttime hours.

When the uptake rates of mud and sand sediments were area-weighted and combined, the benthos in Potter Pond was calculated to consume $100 \mathrm{~g} \mathrm{C} \mathrm{m}^{-2} \mathrm{yr}^{-1}$ during the daytime and an additional $80 \mathrm{~g} \mathrm{C} \mathrm{m}^{-2} \mathrm{yr}^{-1}$ at night.

\section{Benthic production}

Measured rates of light chamber benthic oxygen flux ranged from an uptake of -176 to a production of $+133 \mathrm{mg} \mathrm{O}_{2} \mathrm{~m}^{-2} \mathrm{~h}^{-1}$. Mud-bottom sediments showed a net uptake of oxygen in light chambers at temperatures above 12 to $14^{\circ} \mathrm{C}$, while the sandy tidal flat community always showed a net production of oxygen in the light over a temperature range from 4 to $22.5^{\circ} \mathrm{C}$ (Fig. 5). All 3 sites showed lower net production with higher temperature, suggesting that respiration of the benthos rose faster with temperature than did benthic production (Fig. 5).

Station 1 showed goad correlation between oxygen flux and both light and temperature. The slopes of the 2 regression lines were almost identical, though it is obvious that temperature and light are not truly independent variables. Warm summer water temperatures in the Pond also corresponded with days when daylength was longest and light intensity was highest.

Station 2 showed fairly good correlation between benthic oxygen flux and temperature but no correlation with incident light. It should be noted that although the correlation between oxygen flux and light appears strong at Station 1, the data available are for a much smaller range of light intensities than were obtained at Station 2. Likewise, it appears that all oxygen flux values were negative at Station 2, though no data were collected at temperatures below $15^{\circ} \mathrm{C}$ where oxygen fluxes might presumably have been positive. Multiple regression analysis of light and temperature data for mud-bottom Stations 1 and 2 showed that temperature alone was the best predictor of oxygen flux in light chambers.

As noted earlier, the sandy sub-tidal flat area at Station 3 always showed a net production of oxygen. In this case, the correlation of oxygen flux with light was slightly better than with temperature, and multiple regression analysis showed that both variables should be included in the predictive model.

Based on these results, the temperature regressions shown in Fig. 5 were used with weekly temperature data to predict daytime oxygen exchanges between sediments and the overlying water over an annual
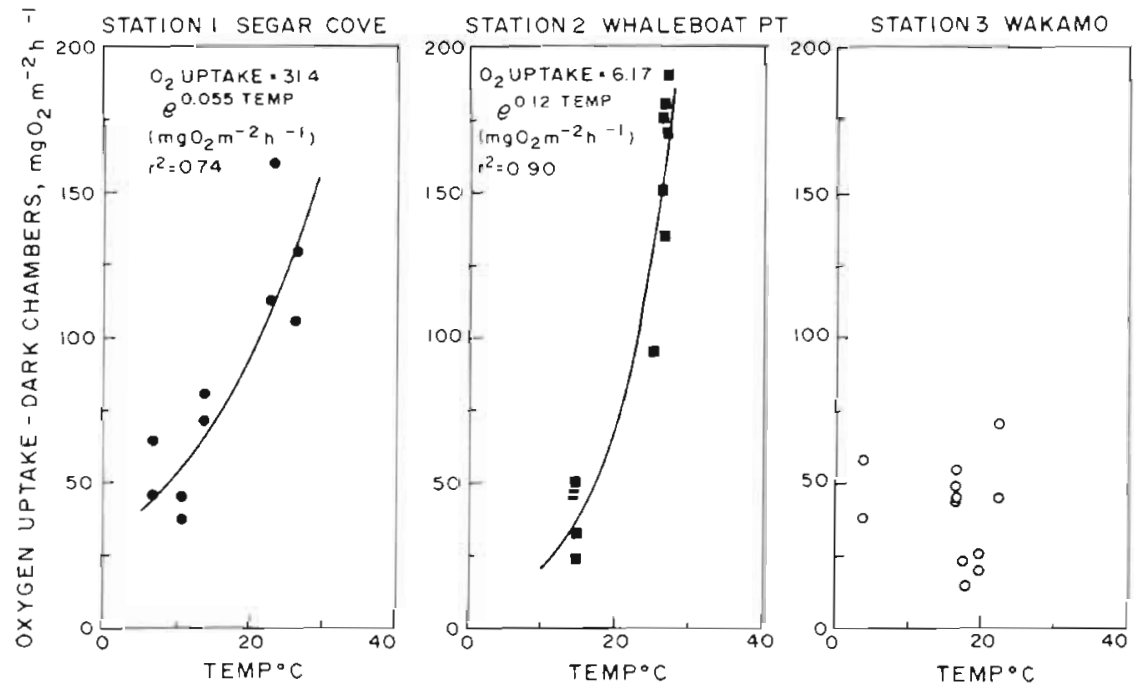

Fig. 3. Benthic oxygen uptake in dark chambers as a function of temperature at each of 3 stations in Potter Pond. Regressions for mud stations are significant at the $95 \%$ level, but the slopes of the 2 lines are statistically not different 

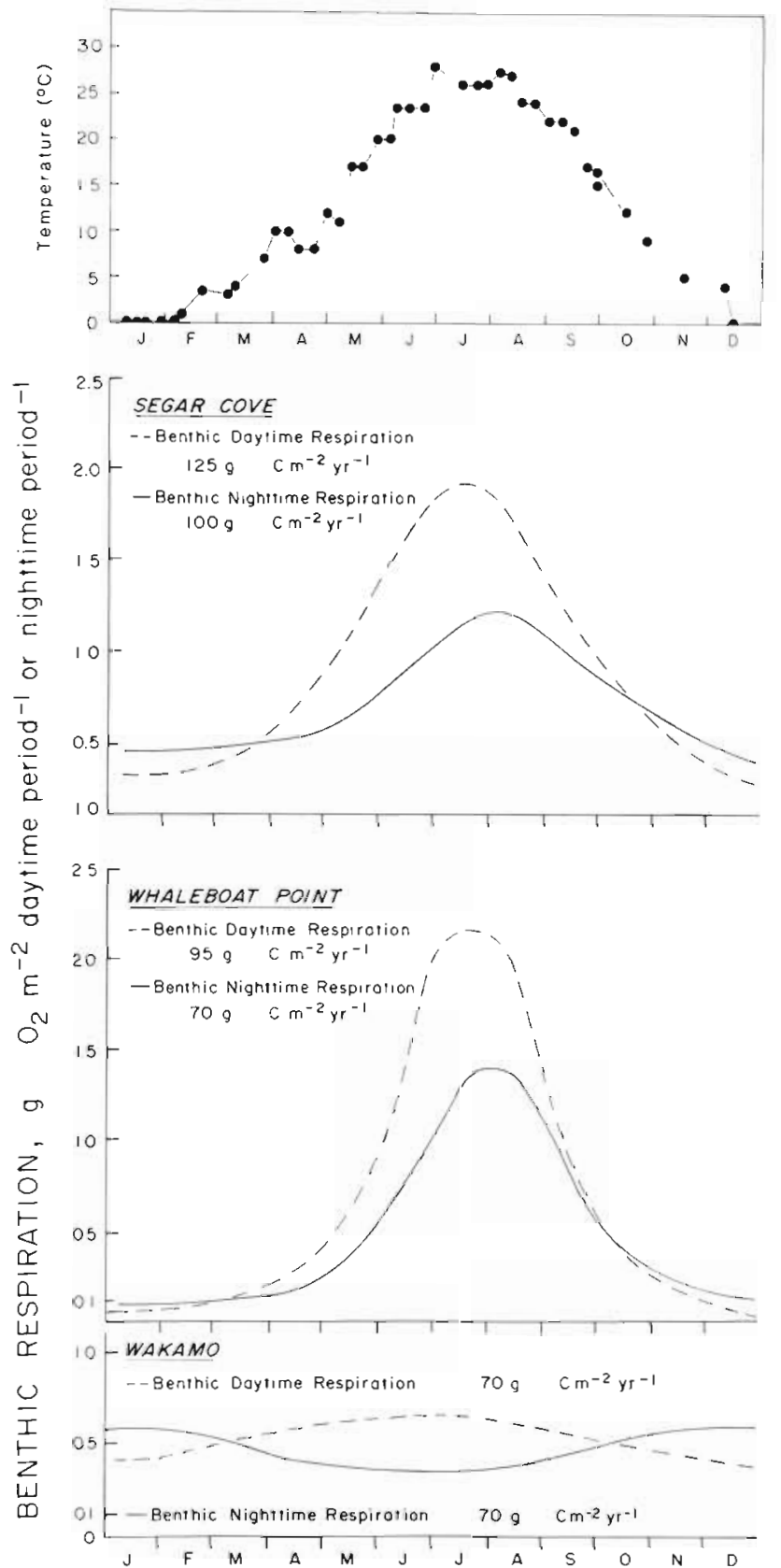

Fig. 4. Annual curves of calculated benthic day (---) and night (-) respiration for 3 stations in Potter Pond, R. I. Although the curves were calculated from the same temperature regressions, daytime respiratory costs exceeded nighttime costs in summer, when longer daytime hours coincided with higher pond-water temperatures

cycle for Stations 1 and 2. A multiple regression of light and temperature $\left(\mathrm{r}^{2}\right.$ of 0.92$)$ was used for an annual prediction at Station 3 where oxygen flux $\left(\mathrm{mg} \mathrm{O}_{2} \mathrm{~m}^{-2}\right.$ $\left.\mathrm{h}^{-1}\right)=135.7-1.79 \mathrm{Temp}\left({ }^{\circ} \mathrm{C}\right)-2.25$ Light (Langleys $h^{-1}$.

The resulting annual curves are shown in Fig. 6. Temperatures above $14.5^{\circ} \mathrm{C}$ at Segar Cove and $12^{\circ} \mathrm{C}$ at
Whaleboat Point yield a negative net oxygen flux. Thus, when Pond temperatures increased in early May from approximately 10 to $17{ }^{\circ} \mathrm{C}$ in $1 \mathrm{wk}$, daytime oxygen fluxes over mud sediments changed from a net production to a net uptake. This net uptake continued through the summer until gradual cooling in the fall left the pond bottom again producing oxygen during the daytime in late October. On an annual basis the calculation for Segar Cove yields a meager $20 \mathrm{~g}$ of $\mathrm{C}$ $\mathrm{m}^{-2} \mathrm{yr}^{-1}$ net daytime production, while Whaleboat Point shows an annual consumption of carbon equivalent to $15 \mathrm{~g} \mathrm{C} \mathrm{m}^{-2} \mathrm{yr}^{-1}$. Given the errors associated with the estimates, it appears likely that neither mudbottom station showed any significant amount of net daytime benthic production annually. Since night respiration consumed $70-100 \mathrm{~g} \mathrm{C} \mathrm{m}^{-2} \mathrm{yr}^{-1}$ in the mud sediments, a substantial amount of organic carbon from some source other than the benthic microflora is needed to meet the metabolic demands of the lagoon benthos. Over sandy sediments, however, rates of net production were always higher than corresponding respiratory consumption, and these areas contributed
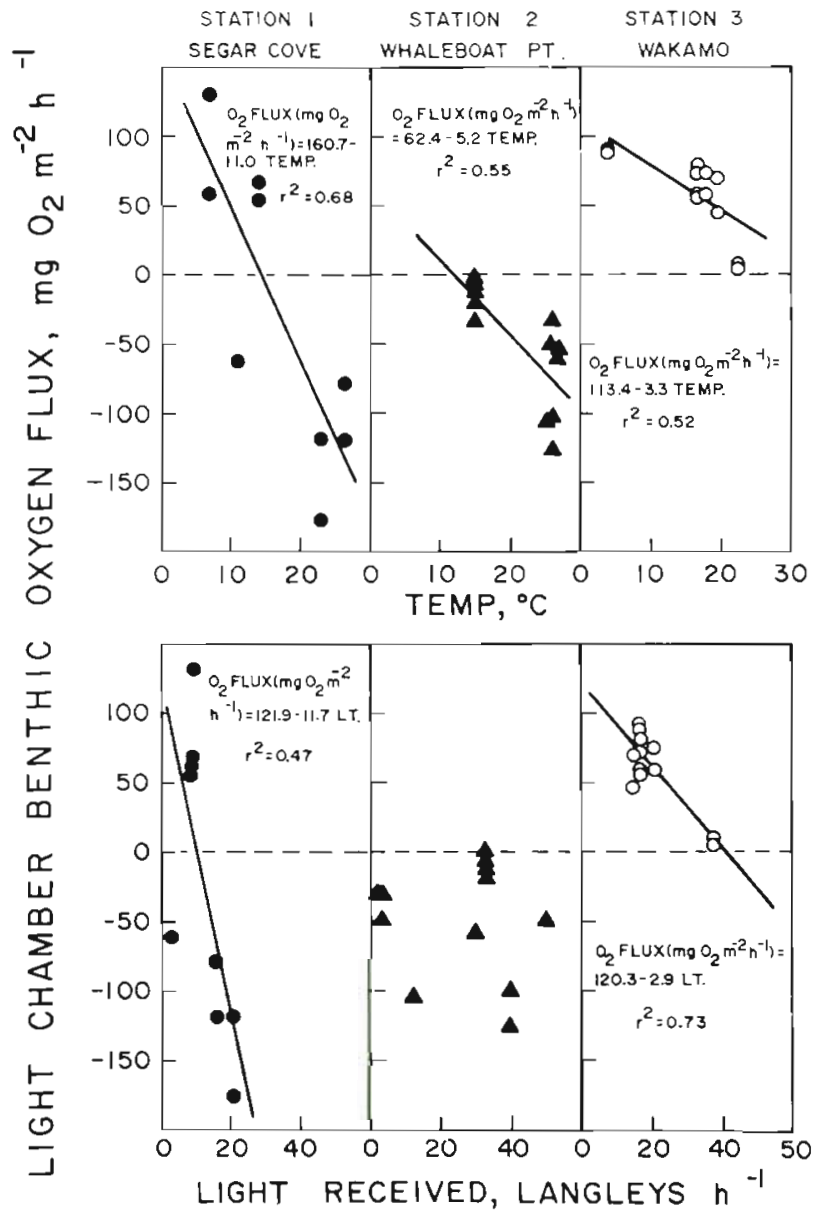

Fig. 5. Benthic oxygen flux in transparent chambers as a function of temperature and light received 


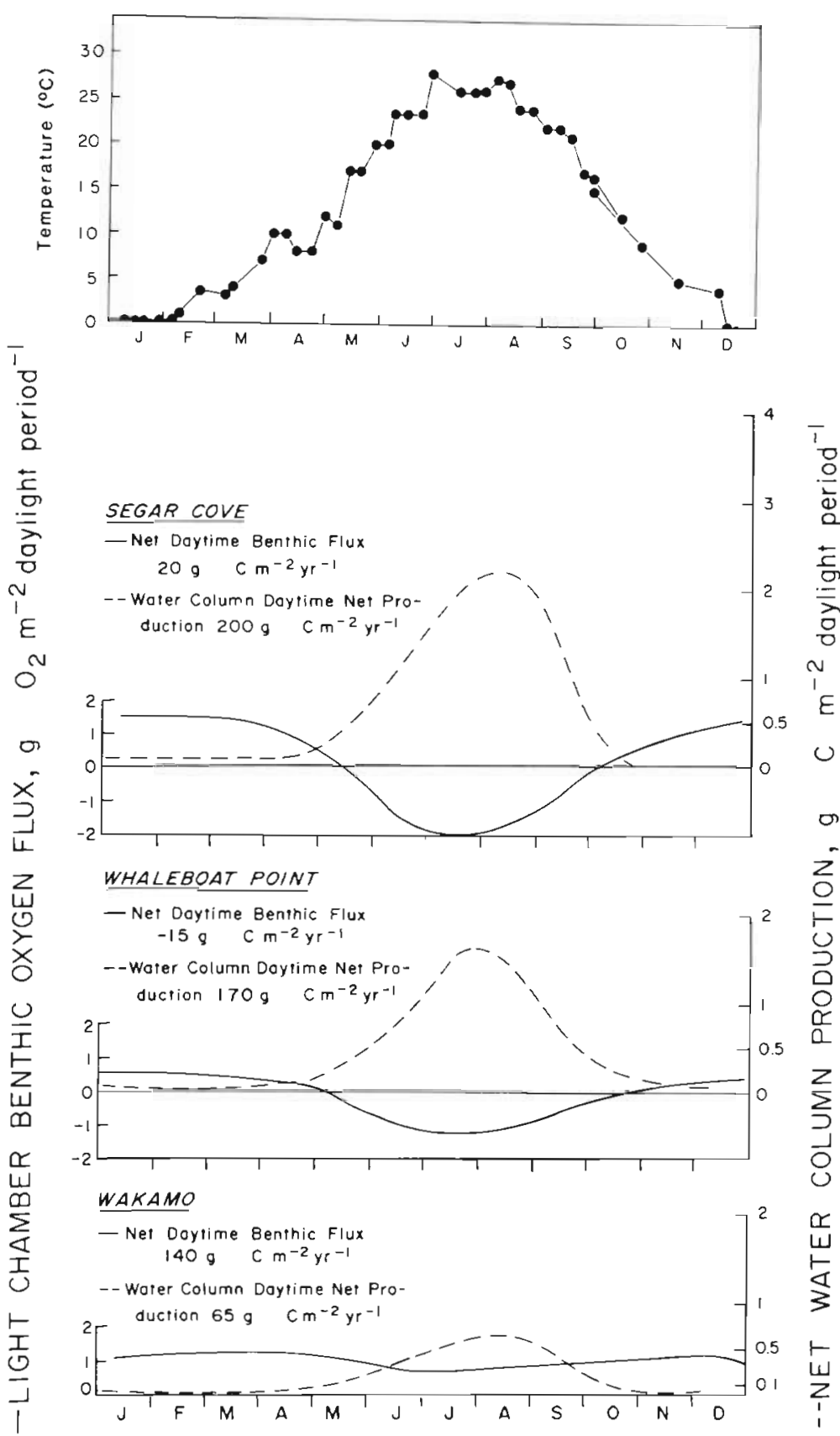

Fig. 6. Annual curves of net daytime benthic flux $(-)$ and net daytime water-column production (-- ) for 3 stations in Potter Pond lagoon. Estimates of daytime benthic flux are derived from regressions of observed light chamber benthic oxygen flux given in Fig. 5 and weekly temperature and light data collected from Oct 1980 to Oct 1981. Integrated annual oxygen production was converted to carbon assuming a $P Q=1$. Estimates of watercolumn production are from Nowicki (1983) with original units preserved some $140 \mathrm{~g} \mathrm{C} \mathrm{m}^{-2} \mathrm{yr}^{-1}$. Area-weighting the annual benthic production at each station by sediment type gave an estimate of total pond benthic daytime production of about $50 \mathrm{~g} \mathrm{C} \mathrm{m}^{-2} \mathrm{Yr}^{-1}$.

Temperature exerted such a strong effect on respiratory rates and, thus, on rates of net production, that it overwhelmed attempts to distinguish possible effects of light on production. Two of the 3 benthic stations sampled showed a fairly good negative correlation between the light received by light chambers and the net oxygen flux (Fig. 5). However, this negative corre- lation is the reverse of what would be expected if light was truly a positive influence on production rates.

To explore possible light effects further, a number of ancillary measurements were made using transparent chambers covered with a $1.6 \mathrm{~mm}$ mesh window screening. Single and double-screened chambers transmitted 45 and $20 \%$ of incident light, respectively. Only when the data from these experiments were separated by temperature was a clear relation with light intensity observed (Fig. 7). At any given temperature the oxygen flux in benthic chambers appeared to increase in a 


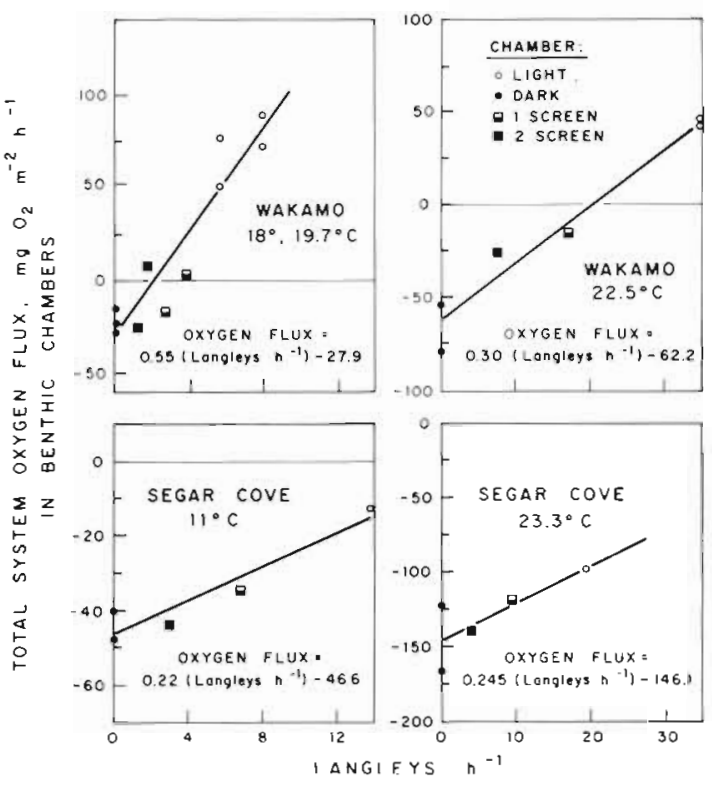

Fig. 7. Total system oxygen flux in benthic chambers as a function of light received. This light effect was observed only when sampling days were segregated by temperature

linear fashion with light received by the bottom community.

Chlorophyll a concentrations in surface sediments ranged from 10 to $460 \mathrm{mg} \mathrm{m}^{-2}$ (mean $=170$ ) for mud sediments and from 15 to $430 \mathrm{mg} \mathrm{m}^{-2}$ (mean $=150$ ) for sandy sediments. These values fall within the range of values reviewed by Colijn \& deJonge (1984) for a variety of shallow-water systems. No clear seasonal trends in sediment chlorophyll a were observed although concentrations tended to be higher and more variable during the months of March and April than for the period from May through October.

\section{DISCUSSION}

\section{Calculation of a carbon budget for Potter Pond}

The light and dark bottle and chamber techniques used in this study measure the net organic production or consumption of the plankton and benthic communities as a whole. Oxygen changes in water-column bottles included respiratory costs of zooplankton and bacteria as well as net production by autotrophs. Measurements using benthic chambers do not distinguish among the metabolism of benthic microalgae, bacteria, and sediment infauna. Furthermore, the carbon consumed by each of these communities was not necessarily produced within the community. The plankton may respire organic material fixed by benthic diatoms or eelgrass and swept into the water column; the benthic community may metabolize organic detritus settling from the water column or from adjacent eelgrass beds as well as that fixed in place by sediment epiflora.

Although the techniques used in this study do not identify the precise origin or fate of carbon within each community of Potter Pond, they do give insight into the quantities involved, and the overall carbon balance. As a first step, the balance between carbon production and consumption by the bottom community can be examined.

Over an annual cycle in Potter Pond lagoon the gross production of the benthic microfloral community on sediments was estimated at $150 \mathrm{~g} \mathrm{C} \mathrm{m}^{-2} \mathrm{yr}^{-1}$. Of this total, some $100 \mathrm{~g} \mathrm{C} \mathrm{m}^{-2} \mathrm{yr}^{-1}$ is needed to cover daytime benthic respiratory costs, leaving a net daytime benthic production of $50 \mathrm{~g} \mathrm{C} \mathrm{m}^{-2} \mathrm{yr}^{-1}$. However, an additional $80 \mathrm{~g} \mathrm{C} \mathrm{m}^{-2} \mathrm{yr}^{-1}$ is required to meet nighttime respiratory costs, so it appears that even if all benthic microfloral production were consumed on the bottom, an additional $30 \mathrm{~g} \mathrm{C} \mathrm{m}^{-2} \mathrm{yr}^{-1}$ would be required to meet benthic respiratory demands (Table 1 ). This additional carbon might come from the production of phy-

Table 1. Comparison of annual carbon budgets $\left(\mathrm{g} \mathrm{C} \mathrm{m}^{-2} \mathrm{yr}^{-1}\right)$ for benthos of Potter Pond and Narragansett Bay

\begin{tabular}{|c|c|c|}
\hline Parameters & $\begin{array}{l}\text { Potter } \\
\text { Pond }\end{array}$ & $\begin{array}{l}\text { Narragansett } \\
\text { Bay }\end{array}$ \\
\hline $\begin{array}{l}\text { Gross benthic daytime produc- } \\
\text { tion }^{1} \text { (microflora }+ \text { sediments) }\end{array}$ & 150 & $\sim 0$ \\
\hline Benthic daytime respiration ${ }^{1}$ & -100 & -70 \\
\hline $\begin{array}{l}\text { Net benthic daytime produc- } \\
\text { tion }^{1} \text { (microflora }+ \text { sediments) }\end{array}$ & 50 & 0 \\
\hline Benthic nighttime respiration ${ }^{1}$ & -80 & -70 \\
\hline $\begin{array}{l}\text { Net annual benthic } \\
\text { consumption }{ }^{1}\end{array}$ & -30 & -140 \\
\hline $\begin{array}{l}\text { Annual phytoplankton } \\
\text { production }\end{array}$ & 120 & 310 \\
\hline $\begin{array}{l}\text { Annual macrophyte } \\
\text { production }{ }^{3}\end{array}$ & $200-300$ & $\leq 1$ \\
\hline Total net production ${ }^{4}$ & $290-390$ & 170 \\
\hline \multicolumn{3}{|c|}{$\begin{array}{l}{ }^{1} \text { Calculated from } \mathrm{O}_{2} \text { uptake and production measure- } \\
\text { ments, } \mathrm{RQ} \text { and } \mathrm{PQ}=1 \text {. Benthic respiration estimates for } \\
\text { Narragansett Bay from Nixon et al. (1976) } \\
{ }^{2} \text { Plankton community production estimated for Potter } \\
\text { Pond by Nowicki (1983) using } \mathrm{O}_{2} \text { changes, and for Nar- } \\
\text { ragansett Bay phytoplankton by Furnas et al. (1976) } \\
\text { using }{ }^{14} \mathrm{C} \text { uptake. The values are not strictly comparable } \\
\text { since some pelagic respiration by heterotrophs is in- } \\
\text { cluded in the measurements of pond water } \mathrm{O}_{2} \text { changes } \\
{ }^{3} \text { Macrophyte production estimated for Potter Pond by } \\
\text { Thorne-Miller and Harlin (pers. comm.) and for the bay } \\
\text { by Brady-Campbell et al. (1984) using biomass incre- } \\
\text { ments and estimates of standing crop turnover } \\
{ }^{4} \text { Exclusive of pelagic respiration in the case of Narragan- } \\
\text { sett Bay }\end{array}$} \\
\hline
\end{tabular}


toplankton or macrophytes within the lagoon, or might be imported from offshore waters or adjoining marshes. A preliminary comparison of particulate carbon concentrations within the lagoon and in offshore waters suggests that the lagoon is more likely to be exporting carbon to offshore waters (Nowicki 1983). Potter Pond has no stream or river inputs and minimal amounts of fringing marsh, so the most probable source of carbon for the lagoon benthos is the production of phytoplankton and macrophytes.

The results of a calculation of this type must be viewed in light of the estimates used to make it and their associated error terms. The most significant of these errors probably lies in the general assumption that results from 3 stations can be used to characterize the Pond as a whole. In addition, although the annual curves are composed of many data points from weekly temperature data for the Pond, each curve is based ultimately on a temperature regression for a limited number of field observations. While the regressions themselves are highly significant at the $95 \%$ level, the small number of available field observations results in large confidence limits about the slopes of the regression lines.

Specific values of $R Q$ and $P Q$ were not available for the water column or benthos of Potter Pond and these numbers had to be assumed from work in nearby Narragansett Bay. The degree to which these values differ from place to place within the coastal waters of Rhode Island, or change seasonally within the same estuary is not known.

\section{Comparison with other shallow marine systems}

Comparison of this study with previous work on shallow-water benthic communities is difficult, due to a great disparity both in the methods of measurement used, and in the analysis and presentation of results. In reviewing the literature it becomes very clear that there is still no conventional method for measuring and reporting estimates of annual primary production in aquatic ecosystems.

A major stumbling block to the comparison of benthic microfloral production in marine systems lies in the fact that the 2 major methods of measurement used $-{ }^{14} \mathrm{C}$ uptake and $\mathrm{O}_{2}$ evolution - describe different quantities. While the ${ }^{14} \mathrm{C}$ method used by Cadée \& Hegeman (1974), Grøntved (1962), Marshall et al. (1971), and others provides a number that lies somewhere between net and gross production, and is a measure of the amount of net carbon fixation by autotrophs during daylight hours, the oxygen method described in this study and used by Pamatmat (1968), van Es (1977) and others provides a net energy balance for the benthos as a whole. Much of the evidence put forth to suggest that the benthic microflora are significant contributors to primary production in shallow coastal systems is based on daytime ${ }^{14} \mathrm{C}$ production measurements. These studies are generally done on surface sediments placed in bottles and they do not include the respiratory costs of the benthic community as a whole. Very little work has been done for which both benthic production and respiration terms are known (Table 2).

To confuse the issue further, studies of benthic remineralization and production span a variety of techniques including in-situ bell jars or chambers, intact sediment cores, and sediment core slurries. Lengths of incubation vary from short 3 or 4 h mid-day incubations to half-day incubations to $24 \mathrm{~h}$ total system measurements. In addition, methods of estimating benthic production on an annual basis differ with each investigator. Often it is not entirely clear whether the author describes net or gross production. The problem encountered with studies of benthic microfloral production is further magnified when one moves to consider the total primary production of shallow water ecosystems, and must include estimates of production for phytoplankton, seagrasses, and macroalgae, each of which is subject to a great variety of uncertainties in measurement.

Oxygen measurements in bell jars made by Pamatmat (1968) in False Bay are the most comparable to this study. Pamatmat worked on an area of intertidal sandflat that was similar to the sandy sub-tidal areas at Wakamo in Potter Pond, though his sites were exposed for some portion of each day. The intertidal zone where Pamatmat worked may have been subjected to extremes of temperature when exposed, but his studies were done only while the sandflats were submerged and he reported a mean monthly water temperature range from 6 to $13^{\circ} \mathrm{C}$, a much more moderate range than the -1.5 to $28^{\circ} \mathrm{C}$ experienced in Potter Pond. Not surprisingly, Pamatmat found that, for the benthos in False Bay, light, rather than temperature, was the single most important factor controlling benthic microfloral production.

It is also interesting to compare the results of this study with information available for the deeper, heterotrophic bottom communities of nearby Narragansett Bay, R. I. (Table 1). Production by benthic microflora or aquatic macrophytes is negligible in the bay (mean depth, $8.6 \mathrm{~m}$ ) and the primary source of organic matter for the benthos is phytoplankton production. Nevertheless, in-situ measurements of oxygen uptake by 3 subtidal bottom communities in Narragansett Bay ranged from 10 to $150 \mathrm{mg} \mathrm{O} \mathrm{O}^{-2} \mathrm{~h}^{-1}$ (0 to $24^{\circ} \mathrm{C}$, Nixon et al. 1976), and are statistically not different from rates observed in dark chamber incubations 
Table 2. Comparison of studies of benthic production and respiration in shallow-water systems. Units are $\mathrm{g} \mathrm{C} \mathrm{m}^{-2} \mathrm{yr}^{-1}$ and have been converted from $\mathrm{O}_{2}$ data when necessary using $\mathrm{RQ}$ and $\mathrm{PQ}$ equal to 1 For a more comprehensive review of ${ }^{14} \mathrm{C}$ studies of microfloral production see Colijn \& de Jonge (1984)

\begin{tabular}{|c|c|c|c|c|c|c|c|c|c|}
\hline \multirow[t]{3}{*}{ Study } & \multirow[t]{3}{*}{ Location } & \multirow[t]{3}{*}{ Depth } & \multirow[t]{3}{*}{ Method } & \multirow{2}{*}{\multicolumn{2}{|c|}{$\begin{array}{l}\text { Production by } \\
\text { benthic micro- } \\
\text { flora only }\end{array}$}} & \multicolumn{4}{|c|}{$\begin{array}{l}\text { Carbon balance for } \\
\text { benthic community }\end{array}$} \\
\hline & & & & & & Gross & Consump- & & \\
\hline & & & & Gross & Net & production & tion & & duction \\
\hline $\begin{array}{l}\text { Grontved } \\
\text { (1962) }\end{array}$ & $\begin{array}{l}\text { Danish Wadden Sea } \\
\text { tidal flats }\end{array}$ & Intertidal & ${ }^{14} \mathrm{C}$ & & $115-180$ & & & & \\
\hline Leach $(1970)$ & $\begin{array}{l}\text { Ythan Estuary, Scotland } \\
\text { intertidal mud flat }\end{array}$ & Intertidal & ${ }^{14} \mathrm{C}$ & & 31 & & & & \\
\hline Marshall & New England Estuaries & $1 / 3-1 \mathrm{~m}$ & 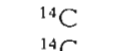 & & 81 & & & & \\
\hline $\begin{array}{l}\text { Cadée \& Hege- } \\
\text { man (1974) }\end{array}$ & $\begin{array}{l}\text { Dutch Wadden Sea } \\
\text { tidal flats }\end{array}$ & $\begin{array}{l}\text { Intertidal } \\
\text { partially } \\
\text { exposed } \\
\text { Submerged }\end{array}$ & ${ }^{14} \mathrm{C}$ & & $\begin{array}{c}58-170 \\
10\end{array}$ & & & & \\
\hline $\begin{array}{l}\text { Van Raalte } \\
\text { et al. (1976) }\end{array}$ & $\begin{array}{l}\text { Great Sippewisset } \\
\text { Marsh, Mass. }\end{array}$ & Intertidal & ${ }^{14} \mathrm{C}$ & & 106 & & & & \\
\hline $\begin{array}{l}\text { Colijn \& de } \\
\text { Jonge (1984) }\end{array}$ & $\begin{array}{l}\text { Dutch Wadden Sea } \\
\text { EMS-Dollard Estuary }\end{array}$ & Intertidal & ${ }^{14} \mathrm{C}$ & & $50-250$ & & & & \\
\hline $\begin{array}{l}\text { Pomeroy } \\
\text { (1959) }\end{array}$ & $\begin{array}{l}\text { Georgia Salt Marsh } \\
\text { tidal flats }\end{array}$ & Intertidal & $\mathrm{O}_{2}$ & & & 200 & 100 & 100 & \\
\hline $\begin{array}{l}\text { Pamatmat } \\
(1968)\end{array}$ & $\begin{array}{l}\text { False Bay, Washington } \\
\text { intertidal sand flat }\end{array}$ & Intertidal & $\mathrm{O}_{2}$ & & & $90-150$ & $80-120$ & $10-30$ & \\
\hline $\begin{array}{l}\text { Hargrave } \\
(1969)\end{array}$ & $\begin{array}{l}\text { Marion Lake, B.C. } \\
\text { freshwater mud }\end{array}$ & $2.2 \mathrm{~m}$ & $\mathrm{O}_{2}$ & & & 40 & 57 & -17 & \\
\hline $\begin{array}{l}\text { Gallagher \& } \\
\text { Daiber (1974) }\end{array}$ & $\begin{array}{l}\text { Lewes, Delaware } \\
\text { tidal marsh }\end{array}$ & Intertidal & $\mathrm{O}_{2}$ & & & 80 & - & - & \\
\hline $\begin{array}{l}\text { Van Es } \\
(1977)\end{array}$ & $\begin{array}{l}\text { Wadden Sea } \\
\text { Dollard Estuary } \\
\text { tidal flats }\end{array}$ & Intertidal & $\mathrm{O}_{2}$ & & & 117 & 196 & -79 & \\
\hline $\begin{array}{l}\text { Van Es } \\
(1982)\end{array}$ & EMS-Dollard Estuary & Intertidal & $\mathrm{O}_{2}$ & & & $\begin{array}{l}116 \\
127\end{array}$ & $\begin{array}{r}71 \\
186\end{array}$ & $\begin{array}{r}45 \\
-59\end{array}$ & $\begin{array}{l}\text { (sandy) } \\
\text { (silt \& } \\
\text { sand) }\end{array}$ \\
\hline $\begin{array}{l}\text { Davis \& } \\
\text { McIntire (1983) }\end{array}$ & Netarts Bay, Oregon & $\begin{array}{l}0.5 \mathrm{~m} \\
\text { above } \\
\text { MLLW }\end{array}$ & $\mathrm{O}_{2}$ & & & $\begin{array}{l}144 \\
168 \\
145\end{array}$ & $\begin{array}{l}109.6 \\
116.2 \\
130.5\end{array}$ & $\begin{array}{l}34.4 \\
51.8 \\
14.5\end{array}$ & $\begin{array}{l}\text { (sand) } \\
\text { (fine } \\
\text { sand) } \\
\text { (silt) }\end{array}$ \\
\hline This Study & Potter Pond, R. I. & $0.68 \mathrm{~m}$ & $\mathrm{O}_{2}$ & & & $\begin{array}{l}120 \\
210 \\
150\end{array}$ & $\begin{array}{l}200 \\
140 \\
180\end{array}$ & $\begin{array}{r}-80 \\
70 \\
-30\end{array}$ & $\begin{array}{l}\text { (mud) } \\
\text { (sand) } \\
\text { (area- } \\
\text { weighted } \\
\text { ave.) }\end{array}$ \\
\hline
\end{tabular}

for mud-sediment areas in Potter lagoon. Oxygen uptake rates in the bay also showed a curvilinear response to temperature and the slope of the exponential curve fit to bay data is not significantly different from the exponentials used to describe dark oxygen uptake at mud-sediment stations in Potter Pond (Fig. 3). However, approximately $35 \%$ of the lagoon bottom area is comprised of sandy sediments with significantly lower rates of benthic respiration. As a result of lower respiratory rates over sand sediments, and production by benthic microflora, the net annual consumption of carbon by the lagoon benthos as a whole appears to be considerably lower than that estimated for the Narragansett Bay benthos. Over an annual cycle, the bay benthos consumed approximately $140 \mathrm{~g} \mathrm{C} \mathrm{m}^{-2}$ in benthic respiration (Nixon et al. 1976) or approximately $45 \%$ of the estimated net phytoplankton production (Furnas et al. 1976). In the lagoon, if all available benthic microfloral production were consumed on the bottom, an additional $30 \mathrm{~g} \mathrm{C}$ $\mathrm{m}^{-2} \mathrm{yr}^{-1}$ would be needed from phytoplankton or macrophyte production to meet benthic metabolic demands.

In spite of often impressive rates of carbon fixation by epibenthic algae, it appears that the benthos of shallow, fine-grained sediments may still constitute a heterotrophic community dependent on organic inputs from other carbon sources within the ecosystem. 
Acknowledgements. We thank Suzanne Heffernan and Larry McKenna for help with the field program, and Stephen Granger and Richard Chinman for assistance in fieldwork requiring SCUBA. Debates and discussions with Candace Oviatt provided valuable information and stimulation. Marilyn Harlin and Boyce Thorne-Miller made their unpublished data available to us. Support for this work was provided by the Office of Sea Grant, NOAA.

\section{LITERATURE CITED}

Brady-Campbell, M. M., Campbell, D. B., Harlin, M. M. (1984). Productivity of Laminaria Spp. near the southern limit in the northwestern Atlantic Ocean. Mar. Ecol. Prog. Sers. 18: 79-88

Cadée, G. C., Hegeman, J. (1974). Primary production of the benthic microflora living on tidal flats in the Dutch Wadden Sea. Neth. J. Sea Res. 8 (2-3): 260-291

Carritt, D. E., Carpenter, J. H. (1966). Comparison and evaluation of currently employed modifications of the Winkler method for determining dissolved oxygen in seawater. J. mar. Res. 24 (3) : 286-318

Colijn, F., de Jonge, V. N. (1984). Primary production of microphytobenthos in the Ems-Dollard Estuary. Mar. Ecol. Prog. Ser. 14: 185-196

Cromwell, J. E. (1971). Barrier coast distribution: a worldwide survey. Abstr. Vol., Second Natl. Coastal and Shallow Water Research Conf. 50: 408

Davis, M. W., McIntire, C. D. (1983). Effects of physical gradients on the production dynamics of sediment-associated algae. Mar. Ecol. Prog. Ser. 13: 103-114

Furnas, M. J., Hitchcock, G. L., Smayda, T. J. (1976). Nutrientphytoplankton relationships in Narragansett Bay during the 1974 summer bloom. In: Wiley, M. L. (ed.) Estuarine processes: uses, stresses and adaptation to the estuary, Vol. 1. Academic Press, New York, p. 118-134

Gallagher, J. T., Daiber, F. (1974). Primary production of edaphic algal communities in a Delaware salt marsh. Limnol. Oceanogr. 19 (3): 390-395

Grontved, J. (1962). Preliminary report on the productivity of microbenthos and phytoplankton in the Danish Wadden Sea. Meddr Kommn Danm. Fisk. Havunders. 3: 374-378

Hargrave, B. T (1969). Epibenthic algal production and community respisation in the sediments of Marion Lake. J. Fish. Res. Bd Can. 26: 2003-2026

Holm-Hansen, O., Lorenzen, C. J., Holmes, R. W., Strickland, J. D. H. (1965). Fluorometric determination of chlorophyll. J. Cons. perrn. int. Explor. Mer 30 (1): 3-15
Leach, J. H. (1970). Epibenthic algal production in an intertidal mud flat. Limnol. Oceanogr. 15 (4): 514-521

Marshall, N., Oviatt, C. A., Skauen, D. M. (1971): Productivity of the benthic microflora of shoal estuarine environments in southern New England. Int. Revue ges. Hydrobiol. 56 (6): $947-956$

Nixon, S. W. (1981). Remineralization and nutrient cycling in coastal marine ecosystems. In: Neilson, B. J., Cronin, L. E. (ed.) Estuaries and nutrients. Humana Press, Clifton, New Jersey, p. 111-138

Nixon, S. W., Kelly, J. R., Furnas, B. N., Oviatt, C. A., Hale S. S. (1980). Phosphorus regeneration and the metabolism of coastal bottom communities. In: Tenore, K. R., Coull, B C. (ed.) Marine benthic dynamics. University of South Carolina Press, Columbia, South Carolina, p. 219-242

Nixon, S. W., Oviatt, C. A., Hale, S. S. (1976). Nitrogen regeneration and the metabolism of coastal marine bottom communities. In: Anderson, J. M., Macfadyen, A. (ed.) The role of terrestrial and aquatic organisms in decomposition processes. Blackwell Scientific Publications, London, p. 269-283

Nowicki, B. (1983). Benthic community metabolism in a coastal lagoon ecosystem. M. S. thesis, University of Rhode Island, Kingston

Nowicki, B. L., Nixon, S. W. (in press). Benthic nutrient remineralization in a coastal lagoon ecosystem. Estuaries

Oviatt, C. A., Buckley, B., Nixon, S. W. (1981). Annual phytoplankton metabolism in Narragansett Bay calculated from survey field measurements and microcosm observations. Estuaries 4 (3): 167-175

Pamatamat, M. M. (1968). Ecology and metabolism of a benthic community on an intertidal sandflat. Int. Revue ges. Hydrobiol. 53: 211-298

Pomeroy, L. R. (1959). Algal productivity in salt marshes of Georgia. Limnol. Oceanogr. 4: 386-397

Van Es, F. B. (1977). A preliminary carbon budget for a part of the Ems estuary: the Dollard. Helgoländer wiss. Meeresunters. 30: 283-294

Van Es, F. B. (1982). Community metabolism of intertidal flats in the Ems-Dollard Estuary. Mar. Biol. 66: 95-108

Van Raalte, C., Stewart, W. C., Valiela, I., Teal, J. M. (1976). Production of epibenthic salt marsh algae: light and nutrient limitation. Limnol. Oceanogr. 21: 862-872

Zeitzschel, B. F. (1980). Sediment-water interactions in nutrient dynamics. In: Tenore, K. R., Coull, B. C. (ed.) Marine benthic dynamics. University of South Carolina Press, Columbia, South Carolina, p. 195-212 